\title{
The Role of Civics Teachers in Implementing Entrepreneurship-Based Distance Learning in Shaping the Character of Students at SMPN 12 Bandung
}

\author{
Rina Mariana ${ }^{1, *}$, Sapriya Sapriya ${ }^{2}$ \\ ${ }^{1,2}$ Universitas Pendidikan Indonesia \\ *Corresponding author.Email: rinamariana@upi.edu
}

\begin{abstract}
The Covid-19 pandemic has brought significant impact on all aspects of human life in the world. Almost all governments across the world implement policy to stop activities outside the house and switch it to activities at home, which is also known as 'stay at home.' The field of education, which is also affected by the policy, must not stop, so that the learning activities are carried out using distance learning while still placing the strengthening of character education as the main focus of Indonesian education. This research aims to determine the role of teacher in implementing civic education using entrepreneurship-based distance learning in building the character of students at SMPN 12 Bandung. The research was conducted with qualitative approach using the case study method. The data collection technique used was observation, interview and documentation. The results show that in pandemic situation, which does not allow the implementation of face-to-face learning process, teachers are required to be creative in designing the distance-learning activities while continue presenting their role in the distance-learning process, which is oriented towards life skills through entrepreneurship-based education that is able to shape the character of students. Therefore, it can be concluded that the presence of teachers in entrepreneurship-based distance learning during the pandemic is often in the spotlight since they are still considered to be the spearhead who determine the success or failure of education implemented to be able to achieve the vision of Indonesian education, namely realizing a prosperous Indonesian society, which is sovereign, independent, and have character through the creation of Pancasila students, who think critically, creative, independent, have faith, believe in God Almighty and righteous, cooperative, and have global diversity.
\end{abstract}

Keywords: Character Education, Distance Learning, Entrepreneurship, Role of Civic Teachers.

\section{INTRODUCTION}

The pandemic condition that is really beyond prediction has brought its own challenges, especially for the field of education because all this time learning activities were dominated by face-to-face learning, and during this pandemic no one can force face-to-face learning in class because the priority considerations are safety and health. Since we cannot predict how long this pandemic will last, so even though if we have to stay at home, activities must continue, whether we like it or not, learning must be carried out remotely via the internet by utilizing various social media features and various options of learning management system (LMS), regardless of the various obstacles and constraints that are later encountered in the implementation of distance learning. Distance learning itself is a set of teaching methods in which teaching activities are carried out separately from learning activities. The separation of the two activities can be either in the form of physical or nonphysical distance (U, Hamzah B. 2007, p. 34) [1]. Physical distance is referred to as location, and non-physical distance is condition. Through PJJ (Distance Learning), teachers and students could possibly be in different locations and even separated by great distance.

Distance learning is learning that prioritizes the independence of students. Teachers can deliver teaching materials to students without having to meet face to face in the same room. This kind of learning that can be done at the same time or at different times, can be a solution for the implementation of learning in the midst of the COVID-19 pandemic.

This type of learning will certainly have both advantages and disadvantages. The advantages are that 
students will be more flexible in learning and the place can be adjusted depending on the situation and conditions. Students will also have more freedom to determine or search for their own learning resources by accessing the internet, etc. However, the weakness is that students cannot socialize with other students and their teachers in real terms, so that it will affect the emotions of the students themselves. In addition, students will highly depend on the internet network if distance learning is carried out online. (Nazerly, 2020) [2].

Challenges for the field of education also arise in the implementation of distance learning. In the survey results from the Indonesian Child Protection Commission (KPAI) in April 2020 in kpai.go.id (2020) [3], it was found that $76.7 \%$ of students stated that they had difficulty and felt bored in doing various tasks remotely while $26.8 \%$ of students stated that they did not find it difficult to do various tasks remotely. The results were based on a survey of 246 KPAI complainants as the main respondents and 1700 comparison respondents from 20 provinces and 54 districts/cities in Indonesia. Furthermore, the results of a survey from the Indonesian Child Protection Commission (KPAI) in April 2020 in kpai.go.id (2020), it was found that only $8 \%$ of teachers understand the using of learning application technology for online learning, but $82.4 \%$ limitedly utilized learning application technology for online learning because it is only limited to using the WhatsApp application, and $9.6 \%$ have never used learning application technology for online learning. These results are based on a survey of 602 teachers as respondents in 14 provinces. Improving distance learning skills is an important aspect, and can be done by implementing a teacher training program in the use of information technology (Afip, 2021, p. 209) [4].

Based on the data obtained from the KPAI survey above, SMP Negeri 12 Bandung took an alternative solution to the problem of students' boredom related to distance learning, namely by implementing the policy of entrepreneurship-based distance learning.

\section{THEORETICAL REVIEW}

The role of the teacher who is the spearhead in determining the success and effectiveness of the teaching and learning process cannot be avoided, the teacher must be creative in designing and directing learning even though the teacher is no longer the only source of learning for students. Referring to the learning model in the 2013 Curriculum which requires students to think critically, teachers should develop their competencies by utilizing advances in information technology. Likewise with books. Books are no longer the only source of knowledge and knowledge. Sources of knowledge and knowledge become very wide open when teachers and students surf the internet.
With internet technology, the world is no longer a wallinsulated space, but an open space without partitions. The learning process is not limited to the classroom, does not depend on a teacher, nor is it limited to textbooks or books in the library because information can be known and analyzed from various sources (Tilaar, 2002, p.11)[6]. Creativity is very important for teachers. Therefore, the mission of educational institutions is to educate future generations to become creative and innovative human beings.

In a pandemic situation that does not allow face-to-face learning to take place, teachers are really required to be creative in packaging learning while still presenting their role in the distance learning process.

Distance learning of Civics that is carried out in the midst of the COVID-19 pandemic must be able to take place with full meaning and strive to fulfill the components of the subject itself. Branson in Wahab \& Sapriya (2011, p. 50) [7] identifies three important components in Pancasila and Citizenship Education, namely Civic Knowledge (civic knowledge), Civic Skills (civic skills), and Civic Disposition (citizenship characteristics).

In the current pandemic situation, character education is needed that develops a golden generation of Indonesia who has a healthy personality with reason, attitude and moral behavior, namely a generation that has living values which include 18 character values developed in the Strengthening Character Education (PPK) movement launched by the Ministry of Education and Culture. Indonesian education and culture through character configuration of heart, thought, taste and exercise (Komalasari, 2017, p. 6) [8].

This is in line with the purpose of character education which is not a new idea in the world of education. History records, around the world, education has had 2 (two) main goals: to help students to be smart and to help students become good. (Lickona, 2012, p 5) [9]. This is the material for building the nation's character where the character is built through 2 (two) models, namely habituation and example. This characteristic behavior is built through a learning process, not a coincidence (Kesuma, D, 2018, p. 92) [10]. The management of character education can be developed through habituation, namely by being taught, accustomed, consistently trained, becoming a habit, becoming a character, becoming a culture. This implementation can be applied from home, class, school, and community (Nimawati, Handayani, F \& Hasanah, A, 2020, p. 148) [11].

\section{METHOD}

The research method applied is qualitative research, which is a research that produces descriptive data in the form of written or spoken words from observable people and behavior (Tanzeh, 2011) [5]. Researcher in this case serves as a key instrument and research results emphasize meaning rather than generalization. 
There are three data collection techniques applied in this study, namely observation, documentation, and interview. This research was conducted at SMP Negeri 12 Bandung, West Java. The object of the research is the $8^{\text {th }}$ grade students and the Civics subject teacher who teaches in the $8^{\text {th }}$ grade.

\section{RESULT AND DISCUSSION}

Distance learning (PJJ) is a series of learning processes that are not easy to implement compared to face-to-face learning. The basic element that distinguishes the two is that students cannot interact directly with the teacher (Monika Teguh, 2015) [12]. This causes limited communication. The impact of these communication limitations is students have limited absorption of information and instructions provided by teachers. Distance learning should focus on student independence (Diana et al, 2020) [13]. Over time, this independence must then be fostered during this pandemic.

In practice, as shown in the data obtained from the results of the KPAI survey, many students experience boredom due to monotonous distance learning with activities that are dominated by many tasks and minimal use of learning application technology.

Good learning is in accordance with the characteristics of students and optimal use of the learning environment (Hariyanto \& Mustafa, 2020) [14]. Every participant students have different characteristics at each age (Masgumelar \& Dwiyogo, 2020) [15], so that teachers need to do a needs analysis regarding the development of students diverse. Each student is unique, so if there are students who have not mastery of learning the teacher should give special treatment in learning (Mustafa \& Winarno, 2020) [16].

The finding obtained from this study is that school adopts a policy by implementing a distance learning program based on entrepreneurship projects with the theme of "Building Food Security \& Family Economy at SMPN 12 Bandung in the Adaptation to New Habit Period during the Covid-19 Pandemic." According to the Principal, this action was taken as an answer to the condition of society in general which is experiencing a decline in economic power and the condition of students who are starting to experience boredom due to monotonous distance learning activities and doing a lot of tasks is dominant.

In the condition of declining economic power and people's purchasing power in the midst of this pandemic, distance learning designed by schools offers an alternative solution to these problems by gradually fulfilling family food needs through efforts to grow crops that are easy and inexpensive by utilizing goods and land at home as a growing media. Students get a project to plant plants that can be harvested within a maximum of 3 (three) months.
The entrepreneurship-based distance learning project implemented is a collaboration of several subjects.

Civics Education is involved in entrepreneurship-based distance learning in collaboration with Science and Social Studies subjects for grade 8 . The focus of the study in Civics subject is related to the character of students that can be shaped through this learning. The entrepreneurial characteristics expected to grow and develop in students through this project learning include: 1. Innovative; 2. Creativity; 3. Have Strong Motivation at Work; 4.

Never Give Up; 5. Hard Work; and 6. Ready to accept the risk of the decisions taken. This is in line with what Meredith in Ali Yusuf Hamali (2017) [17] gives the characteristics of someone who has an entrepreneurial spirit as a person who is (1) confident; (2) task and result oriented; (3) dare to take risks; (4) having the spirit of leadership; (5) future oriented; and (6) originality: creativity and innovation.

Entrepreneurship education is a school's attempt to encourage students' interest in entrepreneurship through learning that contains entrepreneurial knowledge and skills in the midst of a pandemic. In this case the teacher has a very important role and is required to be really creative and understand very well the end goals to be achieved from this learning. Meanwhile, according to Susilo \& Hakam (2014) [18] the factors that encourage entrepreneurship education are preparing materials, providing facilities, providing training, and evaluation.

At the preparation stage, the teacher is really required to master and understand the things that must be done at the beginning before the learning takes place. The teacher preparation stage is begun with teacher self-assessment in which every teacher must have the same perception and determination starting by changing the educational paradigm which is usually done face-to-face to distance learning. The second stage is teacher support, where teachers build support from fellow teachers and balance their own strengths professionally since learning is carried out collaboratively with other subjects.

On the other hand, teachers are also required to be creative and flexible in preparing valuable learning, where students build their own knowledge in their minds based on the situations and conditions they live in when learning takes place in accordance to the needs and characteristics of students. Children will learn better if the learning environment is created naturally. Learning will be more meaningful when students experience what they learn, not just knowing (Andri,Afriani, 2018) [19]. Another important activity in the preparation stage is IHT with the agenda of preparing learning designs. The stages of preparing this learning design begin with an analysis of KD (Basic Competencies), where the teacher analyzes the Basic Competencies as reference material in accordance with the 
educational curriculum of each level, followed by determining the targets and objectives of the competencies to be achieved.

After conducting a basic competency analysis, the next step is the teacher mapping out the essential material where the substance of the essential material is determined by emphasizing the needs of the core material, adjusting the material that is in the same scope so that it becomes a single unit.

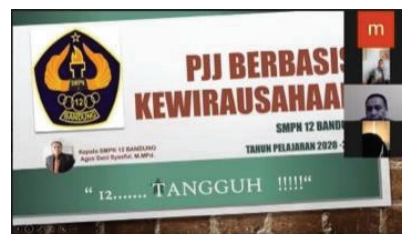

Socialization to teachers

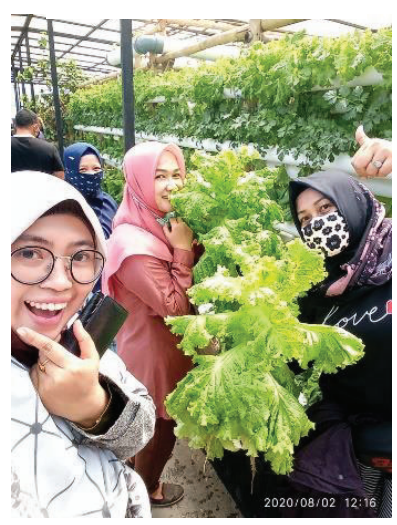

Teachers are observation to plant culvitation
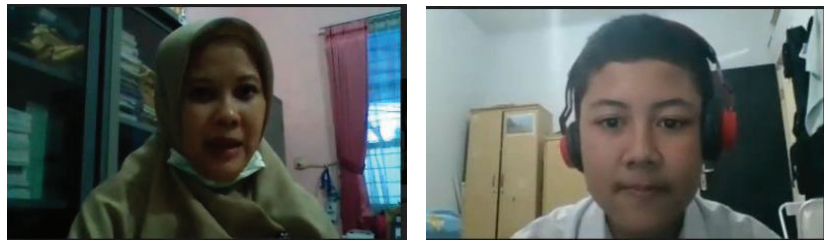

Teacher coaching to students during entrepreneurship project to portofolio preparation

The learning model determined by the teachers of across subjects is a project with attention to the mastery of life skills which is the embodiment of $21^{\text {st }}$ century learning skills with its 4 C's: Critical Thinking, Creativity, Collaboration and Communication. The results of the project carried out within 3 (three) months is that students reported it in a portfolio of assignments either through video, PPT, or written report presentations. The portfolio report is accompanied by a digital poster made as a skill from the implementation of students' mastery of material in understanding the material of Legislation in the National Legal System. Thus, the project assignment portfolio is also one of the assessments used where its position is as an assessment of learning that shows an assessment throughout the learning process, as an assessment for learning that functions to improve future learning and assessment as learning which shows the final result or summative assessment, which is carried out after students go through a series of learning processes. As Komalasri (2017) [20] stated that in general, the assessment of learning outcomes aims to (a) determine the level of achievement of students' competencies; (b) measure the growth and development of students' abilities; (c) diagnose students' learning difficulties; (d) find out the learning outcomes; (e) find out the achievement of the curriculum; (f) encourage students to learn; and (g) encourage teachers to have better teaching skills.

The interesting point resulted from the research is that with entrepreneurship-based distance learning applied, the majority of students actually did not put the crops harvested for sale. They expressed concern over the condition of the community in the midst of this pandemic that they did not sell it for food security and the family economy as the theme carried. Far beyond expectations, they shared their crops with neighbors around their house. This shows the success of character education which is a series starting from after studying the material, students know the goodness of obeying the laws and regulations, then there is a sense of love and desire for goodness and realizing that goodness. This is in line with what was stated by Lickona (1992) [21] who emphasized the importance of three components of good character, where good character consists of knowing the good, loving or desiring the good, and acting the good.

\section{CONCLUSION}

The current Covid-19 pandemic has brought many changes to people's lives. There is an assumption that character education so far tends to be stagnant and only on the order of concepts. Character building becomes a big homework, especially in a pandemic situation like today where learning is not carried out face-to-face but rather remotely, dominantly based on IT. Quite often educators are confused about assessing the character of students, especially when they cannot meet face to face. However, this can be circumvented by creativity and optimizing the teacher's role in learning. From the results of research on the implementation of entrepreneurship-based distance learning conducted at SMPN 12 Bandung, it can be seen that the formation of creative, independent, responsible and caring characteristics can be built through entrepreneurship project assignments.

The current situation and condition, which is supported by the government's policy to carry out work from home and school from home, actually opens the door for maximum collaboration between teachers at school and 
parents at home in the terms of shaping the character of students.

\section{AUTHORS CONTRIBUTIONS}

Rina Mariana is the $1^{\text {st }}$ author of this article who devotes his attention to education, especially at the junior high school level.

Sapriya is the $2^{\text {nd }}$ author of this article as a mentor of writing articles on educational research results.

\section{REFERENCES}

[1] Uno B. Hamzah. Model Pembelajaran. Jakarta. Bumi Aksara. 2020.

[2] Nazerly, M. K. Implementasi zoom, google classroom, dan whatsapp group dalam mendukung pembelajaran daring (online) pada mata kuliah Bahasa Inggris Lanjut (Studi kasus pada 2 kelas semester 2, Jurusan Administrasi Bisnis Fakultas Ekonomi dan Bisnis, Universitas Bina Bangsa. Aksara Publik, 2020, 4 (2), pp. 155-156

[3] kpai.go.id., 2020

[4] Afip Miftahul Basar. Problematika Pembelajaran Jarak Jauh Pada Masa Pandemi Covid-19. Edunesia : Jurnal Ilmiah Pendidikan. Pp. 208-218.

DOI: https://doi.org/10.51276/edu.v2i1.112

[5] A. Tanzeh, Metodologi Penelitian Praktis. Yogyakarta: Teras, 2011.

[6] Tilaar, H.A.R. Membenahi Pendidikan Nasional. Jakarta. Rineka Cipta. 2002.

[7] Abdul Aziz Wahab \& Sapriya. Teori dan Landasan Pendidikan Pancasila dan Kewarganegaraan, Bandung, Alfabeta, 2011.

[8] Kokom Komalasari, Pendidikan Karakter Konsep dan Aplikasi Living Values Education, Bandung, Refika Aditama. 2017.

[9] Lickona, T. Character Matters, Jakarta, Bumi Aksara, 2012.

[10] Kesuma, D, Triatna, C \& Permana, J. Pendidikan Karakter Kajian dan Praktik di Sekolah. Bandung. Remaja Rosdakarya. 2018.

[11] Nimawati, Handayani, F \& Hasanah, A. Model Pengelolaan Pendidikan Karakter Di Sekolah Pada Masa Pandemi. Fastabiq: Jurnal Studi Islam. ISSN 2723-0228 Volume 1 Nomor 2, pp. 145-156.

[12] Monika Teguh. Difusi Inovasi dalam Program Pembelajaran Jarak Jauh di Yayasan Trampil
Indonesia. Jurnal Scriptura, vol. 5 (2), 2015, ISSN: 1978-385X, pp. 71-78

[13] Diana, P. Z., Wirawati, D., Rosalia, S. (2020). Blended learning dalam pembentukan kemandirian belajar. Alinea: Jurnal Bahasa, Sastra, dan Pengajaran 9 (1), 16 - 22, 2020.

[14] E. Haryanto, \& Mustafa, P.S. Pengajaran Remedial dalam Pendidikan Jasmani. Banjarmasin: Lambung Mangkurat University Press, 2020.

[15] Masgumelar, N.K. \& Dwiyogo, W.D. 2020. Development of Game Modification Using Blended Learning in Physical Education, Sports, and Health For Senior High School Students. The 3rd International Conference on Sports Sciences and Health 2019 (ICSSH 2019). Atlantis Press, hal.95100 .

[16] Mustafa, P.S. \& Winarno, M.E. 2020. Pengembangan Buku Ajar Pengajaran Remedial dalam Pendidikan Jasmani untuk Mahasiswa S1 Pendidikan Jasmani dan Kesehatan Universitas Negeri Malang. Multilateral Jurnal Pendidikan Jasmani dan Olahraga, 19(1), 1-12.

[17] Arif Yusuf Hamali, Pemahaman Kewirausahaan. Jakarta, Prenadamedia, 2017.

[18] Susilo, W. R. H., \& Hakam, M. S. (2014). Upaya Dinas Koperasi UKM Dalam Menyelenggarakan Pendidikan Dan Pelatihan Kewirausahaan Untuk Meningkatkan Motivasi Berwirausaha. 12(1), 1-8.

[19] Andri Afriani, Pembelajaran Kontekstual (Contextual Teaching and Learning) dan Pemahaman Konsep Siswa, Jurnal Al-Mutaáliyah STAI Darul Kamal NW Kembang Kerang Vol. 1 (3), 2018, ISSN: 2502-2474

[20] Thomas Lickona, Character Development in School and Beyond, Jakarta, Gramedia, 1992. 